\title{
The Development Of Spell Checker Android Application To Improve Students' Pronunciation Of English Education Department, IAIN Jember
}

\author{
Sari Dewi Noviyanti, sari.dewinoviyanti@gmail.com, IAIN Jember, Jember, \\ Indonesia
}

\begin{abstract}
Pronunciation and vocabulary are important elements of the language so communication will be difficult when the language elements or words are pronounced incorrectly. However, in learning in class, limited time causes lecturers to have difficulty checking the pronunciation of English students one by one. So that technology is needed to improve students' pronunciation competence independently and measurably. This study aims to develop a spell checker application that is integrated with the lecture module. This application aims to improve the English pronunciation ability of students independently and measurably to save time. The research method is a design and development method with 6 stages. The product validation results showed that this application is feasible to use with the acquisition of a feasibility percentage of $89 \%$.

Keywords: pronunciation, spell checker
\end{abstract}

\section{A. INTRODUCTION}

In language learning, there are two main competencies, namely productive and receptive language competencies. Productive competencies include the ability to speak and write, while receptive competencies include the ability to listen and read. However, the ability to speak becomes the first ability to be noticed when communication takes place. As stated by Vina \& Utami., (2019), pronunciation is the initial thing that gets attention from a native speaker. Good communication will be difficult to develop if the speaker has incorrect grammar and vocabulary. In fact, native speakers possibly able to get a person's speech, regardless of their grammatical mistakes, if their interlocutors use accurate pronunciation.

The main purpose of conducting the teaching and learning process in any language is about helping students to communicate with target language users. But in reality, talking with teachers and friends in a foreign language is considered enough for many students. Though it is a big mistake. There are many reasons why this is called a mistake. First, bad English is approved among teachers and student's communication. Second, classroom communication between students conducted in a condition in which they approved each other's mistakes and incorrect pronunciation. Third, the chance to speak with a native speaker is rarely found by students which makes the classrooms learnings are far from the real situation.

Though the role of English pronunciation is emerged to be conducted most properly, this skill does not get enough attention from many educators. As Pourhosein, (2012) states the pronunciation of English is one of the fields that are least liked by educators to be taught in their classrooms. It also can be related to Olaf, (1963) statement that English pronunciation is rarely included in the curriculum because the focus of English teaching is only on the four skills namely speaking, writing, listening, and reading. Many teachers do not realize the importance of pronunciation. Teachers pay attention to grammar and vocabulary in learning foreign languages and help students become skilled in listening and reading. Second, most teachers argue that learning pronunciation is not easy to be conducted and found tedious by students 
(Fromkin, V, R Rodman, 2014). Those arguments then are debated by Levis \& Suvorov, (2014) which stated that English pronunciation teaching and learning problems commonly caused by inappropriate teaching materials and time limitations which make the pronunciation practices are not sufficient enough for students. Other problems found, paying attention to pronunciation practices is just a waste of time and takes lots of energy. Pronunciation ability is considered a skill that can be learned by students independently without any specific instruction from the teachers.

From preliminary research that has been done, it was found that learning pronunciation in class does not use teaching materials. Also, learning in the classroom is still dominated by presentation activities. Lecturers also have limited time to check the pronunciation ability of all students so that the development of the ability of each student cannot be measured with valid. Based on the problems mentioned above, this research aims to develop teaching materials that are integrated with an Android application-based intelligence artificial spell checker that can check the pronunciation of each student accurately and measurably. So the focus of this study refers to 3 aspects, namely 1) the design of teaching materials assisted by an Android spell checker application based on artificial intelligence; 2) the development of teaching material assisted by an android application based on the artificial intelligence spell checker and 3) the quality of teaching material assisted by an android application based on the artificial intelligence spell checker.

Shannon, (2014) conducted a study on improving students' pronunciation skills by applying pronunciation learning based on sound detection technology. The conclusion of the research when learning is integrated with technology can help students feel more independent, especially in terms of pronunciation. Dwi, (2015) researched the use of games to improve the pronunciation skills of elementary students. The results of the study show that with the use of games, pronunciation learning becomes more fun. Çakici, (2016) in his research found that the implementation of technology in the context of foreign language learning can improve problem-solving skills and provide opportunities for students to use high-level skills and develop critical thinking and effective information processing. Technology also encourages independent, autonomous, and active, and collaborative language learning motivates and facilitates language learning, and enhances the ability of teachers. Thus, technology is very important to be integrated into teaching foreign languages as an effective complementary tool.

Yolanda, (2017) in his research entitled the contribution of technology to the teaching of pronunciation competence shows students really like learning pronunciation which is integrated with technology. The results indicate that students prefer pronunciation learning that is integrated with technology compared with conventional learning. Ambra, (2017) in her experiment also found that pronunciation training with a computer-aided system with a simple automatic speech recognition component can improve the ability of students compared to conventional pronunciation teaching. Hernawan, (2010) conducted a classroom action research for students of STIBA Persada Bunda. This research aimed to improve students' pronunciation of the ending "s" sound. This research proved that the use of the android application in the application store could improve students' pronunciation, especially sounding ending "s". Another research was done by Murphy, (2014) which focused on the development of a speak app as an android application to improve students speaking competence. This research revealed that the use of technology could significantly improve students speaking competency. Pourhosein, (2012) conducted a research about teachers' perspective about the use of technology to teach pronunciation competence. The result of this research showed that teachers felt 
interested to use technology to teach pronunciation because it has higher level of pronunciation accuracy.

Those researches have similarities with this research as the focus of how to implement technology in teaching. However, this research has its distinction since it is focus on the development of spell checker android application which is easy to use for both lecturer and students. This is a special android application because it could validate someone' pronunciation is correct or wrong, it has locked-learning stages features and complete sounds exercises. This research will focus on a development of supplementary teaching materials in teaching and strengthening courses that are assisted with Android applications, namely the spell checker where the application is an application based on artificial intelligence which can detect whether a pronunciation is correct or still needs to be corrected again. The existing technology is only limited to sound detection that will transmit sound into text form. But until now there has been no application that can be a helper position as a teacher who is able to state that a pronunciation is declared true or not true.

\section{B. METHOD}

This research can be categorized as Design and Development (Design and Development) proposed by Preffers in Ellis \& Levy, (2010). This refers to the design and development of a product using a 6-phase model namely: a) identifying the problem that motivates research; b) describe the purpose; c) design and develop artifacts; d) subject of artifacts for testing; E) evaluating the test results; and f) communicating the results.

Problem identification is done at the beginning of the study. The problem is the limited time in teaching pronunciation competence. The purpose of the study was done after identifying the problem itself. The purpose of this study are: 1) to find out the design of teaching material for pronunciation assisted by android spell checker application based on artificial intelligence, 2) to identify the development of teaching material for teaching assisted android spell checker application based on artificial intelligence, and 3) to identify the quality of teaching material for pronunciation assisted application android spell checker based on artificial intelligence. Thus, the design and development of learning materials is carried out to meet these objectives. Design and develop artifacts based on purpose. In this case, the material for teaching teaching material assisted by an android application based on artificial intelligence spell checker is an artifact developed in this study. Design and develop teaching materials for pronunciation aided by the Android Spell Checker application based on artificial intelligence with the themes used in the pronunciation course. Artifact testing is carried out to determine whether the artifacts being developed fulfill the functions and requirements set for them during the design and development stages. The validation sheet and expert judgment are the instruments used to check whether the artifacts have met these aspects or not. Evaluation becomes the next stage because it is an important part of making decisions about the testing carried out by experts whether the product needs to be revised or not. After all tests have been completed, the final step is to communicate the results of the test. In this case, the communication is carried out after the results of tests conducted by experts. This is also an important step where comments and input are obtained for the advancement of the product because they are used as instruments for further research.

This type of research is development research. Development research is research that aims to produce or develop a product. According to Gay, LR, (1987), development research is an attempt to develop an effective product for school use, and not to test theory. Meanwhile, according to Borg \& Gall, (1989), research and development is a process used to develop and validate educational products.

143 | IJET| Volume. 9, Issue 2. December 2020

Copyright 2020 Sari Dewi Noviyanti is licensed under Creative Commons Atrribution- ShareAlike 4.0 International License. 
A number of instruments were used to assist researchers in gathering data for this study. The first instrument used in conducting this research was the syllabus of the pronunciation course. Syllabus is used as a parameter to find out whether the development of teaching materials is in accordance with the demands of the curriculum used. Second instrument is checklist. According to (Quinn 2003), the purpose of the checklist is to guide evaluators in (1) choosing a qualitative approach that is very appropriate for the intended use of evaluations and answering evaluation questions, (2) collecting quality and credible qualitative evaluation data, and (3) analyzing and reporting findings qualitative evaluation. The checklist can be used as an instrument to evaluate research results. The checklist instrument that will be used in this study consists of several items or criteria as an evaluation of learning material that will be developed by researchers. Checklist (checklist) will be used by experts to find out whether the learning material to be developed can be applied or not. Third instrument is expert judgment. It is an expression of opinion based on information, based on knowledge and experience that according to experts is in accordance with technical problems. Experts are people who have backgrounds in the subject area and are recognized, who meet the requirements to overcome technical problems. Expert judgment is used in this study to assess or evaluate the teaching materials of pronunciation aids based on the Android spell checker application based on artificial intelligence. Expert judgment will be very strong as an evaluator to validate research data. Using expert judgment in a study must consider several criteria to make the study reliable and valid. The evaluation criteria for experts in this study are the first, a minimum of two experts. There are two ways in which expert groups can be used. One is individual expert judgment, and the other is making them work together in groups and doing assessments. The experts in this research surely must be people who are concerned about the development of education and also have high competence about teaching and learning process, especially teaching English.

The data collection method consists of three main steps, namely 1) design and development of artifacts, 2) artifact testing, and 3) and evaluation of test results. The design and development of artifacts begins with designing and developing artifacts by surveying documents related to teaching material. Next, artifacts are tested by experts to check their application. The syllabus of the course is used as a basis for designing and developing teaching materials based on the application of android spell checker based on artificial intelligence. The material is designed and developed by considering several factors, such as: learning materials in the syllabus, appropriate pronunciation learning materials, and also criteria for good teaching materials. After being designed and developed, learning materials undergo expert assessments to be examined before their application in class. The test is carried out by providing a checklist sheet and a validity form for expert judgment. Evaluation is done as a final step to reflect the test results in order to make the right decision regarding the product. The final revision is important here to ensure there are no errors in the product so that it can be used for further research.

Data were analyzed descriptively. The description statistics will be used for expert validation data sheets which include three components namely content, appearance, and language. Tabulation and data reduction are used to classify data from expert test results to find out obtaining data analysis. Scores from experts who evaluate the quality of teaching materials are analyzed by calculating the average of each expert test result for each component, namely content, appearance, and language. Criteria were made to determine whether this research was successful or not. The success of this study is determined by several criteria, namely compliance with the syllabus, conformity with the criteria of good teaching material components and also supported by the results of expert judgment whose minimum score must be at intervals of 3.1-4.0 (which is categorized as "good" from the interval 0.0-5.0) and if the Alpha reliability results are

144 | IJET| Volume. 9, Issue 2. December 2020

Copyright 2020 Sari Dewi Noviyanti is licensed under Creative Commons Atrribution-ShareAlike 4.0 International License. 
above .60. If all the criteria are reached, then the teaching material can be categorized as feasible to use.

\section{C.RESULT AND DISCUSSION}

Spell Checker Media is used to answer the problems of students in the English Education Study Program who have difficulty pronouncing English words. The limited learning activities in the classroom also cause the lecturer is unable to check the English pronunciation of students one by one. So, the spell checker learning media is developed to complement the existing syllabus and present pronunciation exercises that can be accessed independently by students. However, despite being independent, this exercise can be ensured measurable because there is a lock feature in which students cannot proceed to the next exercise if they have not completed the previous exercise. The syllabus and some criteria for good learning media guide the development of this spell checker media. Accuracy of the media with the syllabus can be seen from in-depth exploration of all syllabus components and both from mind mapping and also indicators of achievement. The results of the in-depth exploration of the curriculum itself are then applied in the development of media which can be seen from the development of the types of exercises that exist in the application, the level of difficulty, integration with modules, as well as images and language to support the learning process. Learning media is also designed to meet 8 good media criteria, namely: 1) according to the needs of students, 2) easy to use, 3) easy to reach, 4) functioning well, 5) engenders interaction, 6) is organized, 7) can connect related parties , 8) safe to use. In addition, as with other technology-based media, the development of spell checker media also refers to the criteria of good media according to Educational Development and Technology, as follows: 1) has a good composition structure, 2) easy to use by teachers and students, 3) can help the learning process in explaining concepts and features, and 4) can help achieve learning objectives.

There are three major steps in developing this learning media, namely design and development, product testing and product evaluation. All stages are developed in a very good way to get high quality products, in this case the spell checker learning media in order to improve the competence of students' English pronunciation. Designing and developing products includes all steps from preparation to manufacturing. The first step that must be done is to study the curriculum. The author explores each part of the syllabus to gain an in-depth understanding of the standards and basic competencies stated in the syllabus to be applied in further textbooks. Curriculum analysis includes the study of standard competencies and basic competencies. Basic competence is then distributed to several indicators and materials. Further subjects that have been identified are mapped and compiled. The next step is to set the goals of the learning process itself.

Before developing learning media, the writer needs to know the learning objectives of the course. By knowing that, the writer can design what types of activities should be provided in the learning media to help students achieve the students' competencies expected in the curriculum. Completing with curriculum exploration and student competencies, the next step is to choose the material and activities to be provided in the media. This includes the type of material, the type of exercise, the level of difficulty, layout and also the language that will be used in the media. The next step is to choose the training material that will be used in learning media. This step includes the process of gathering material, collecting sample questions as well as independent practice questions. Developing a product is the next step after the researcher is ready with all the preparations. This is the stage when the researcher arranges, matches and adjusts the contents of the learning media. The development of this learning media focuses on three

145 | IJET| Volume. 9, Issue 2. December 2020

Copyright 2020 Sari Dewi Noviyanti is licensed under Creative Commons Atrribution- ShareAlike 4.0 International License. 
main components, namely the content of the media, the layout / layout and also the language used in the application. After completing the development of the spell checker application, the next step is to validate it from the experts. All stages carried out in the development of the spell checker application are in accordance with the 6 main steps of development learning material stated by the (Ministry of National Education 2004), namely 1). Study the curriculum, 2). Determine the competencies of students / children that need to be achieved, 3). Select and arrange the material to be presented, 4). Select and arrange the type and study material, 5). Develop learning materials, and 6). Evaluation of learning material. This shows that the development of this media is in accordance with the standard process of developing learning materials stated by the Ministry of National Education.

To find out the quality of the product, it is very important to test this spell checker application to get validation for the quality of the media. The testing of the spell checker application is done by asking two experts to validate the media and asking for some comments or suggestions for revision or evaluation in the next step. The test covers the main components of media such as content, layout and layout of media and language display. As stated by(Booker 2001), the use of interactive media in teaching and learning can provide benefits, namely: 1) enabling creative work 2) saving time 3) replacing ineffective learning activities and 4) increasing discussion time. Validation test is done by asking experts to fill out an expert assessment questionnaire about the quality assessment of the spell checker application. There are 3 main components such as content that contains 8 validation items, a layout that contains 7 validation items and a language that contains 5 validation items. So the sum of all items is 20 items. The scale used in validation is $1-5$, that is 1 which means very bad, 2 is bad, 3 is enough, 4 is good, and 5 is very good. After completing the application, the next step is to get validation from the experts. The experts who validate this media are the Head of English Tadris Program and one of the lecturers supporting the Pronunciation course in English Education Study Program IAIN Jember. Validation is done by criticizing the application based on three components: content, layout and language. The results of the first expert are 15 items given a score of 4 and 5 items with a score of 5. However there are some suggestions for revising the contents and layout sections. The results of the second expert are 17 items given a score of 4 and 3 items with a score of 5. The results of the expert evaluation evaluation are then analyzed with a Likert Scale and the average score of the results of the expert evaluation evaluation is 3.85 which means the learning material developed is good learning material. The results were also analyzed with the Alpha formula to determine the reliability of the product being developed. The score for the Alpha analysis is 0.897 which means that the product developed is reliable. All statistical results show that the spell checker application developed is a good learning media. All of the statements above indicate that the media has good quality and the development of spell checker learning media to improve English pronunciation competence in English Education students can be considered successful.

\section{D.CONCLUSION}

This research is a product development research in the form of a spell checker application that is expected to improve the ability of English pronunciation competency students of the English Language Study Program IAIN Jember. This application was developed by referring to the criteria of good learning media namely 1) having a good composition structure, 2) easy to use by teachers and learners, 3) can help the learning process in explaining concepts and features, and 4) can help achieve learning objectives. This spell checker application also goes through 3 stages of development, namely product

146 | IJET| Volume. 9, Issue 2. December 2020

Copyright 2020 Sari Dewi Noviyanti is licensed under Creative Commons Atrribution-ShareAlike 4.0 International License. 
design, product development and product evaluation. The results of the product validity test stated that this spell checker application has good quality and is suitable for use in learning activities. The future research is expected to continue this research by analysis of effectiveness of this application in classroom to increase students pronunciation

\section{E. REFERENCES}

Ambra, N. (2017). The Effect of Computer Assisted Pronunciation Training (CAPT) System to Improve Word-Level Pronunciation Skills in English as A Foreign Language. Journal of Coumputer and Language Learning.

Borg, W. R., \& Gall, M. D. (1989). Educational Research: An Introduction (7th ed.). Pearson.

Çakici, D. (2016). The Use of ICT in Teaching English as A Foreign Language. Perjournal, 73-77.

Dwi, N. (2015). Improving Students' English Pronunciation Ability through Go Fish Game and Maze Game. Dinamika Ilmu. https://eric.ed.gov/?id=EJ1121925.

Ellis, \& Levy. (2010). Panduan Untuk Peneliti Novice: Desain Dan Metode Penelitian Pengembangan. Prosedur Menginformasikan Pengawasan Ilmu Pengetahuan. InSITE.

Fromkin, V, R Rodman, N. H. L. (2014). An Introduction to Language. Cengage.

Gay, LR, P. A. (1987). Educational Research: Competencies for Analysis and Application Columbus. Merrill Publishing.

Hernawan. (2010). Pengembangan Bahan Ajar. Universitas Pendidikan Indonesia.

Levis, \& Suvorov. (2014). Automated Speech Recognition. Chapelle Publisher.

Murphy, J. (2014). Intelligible, Comprehensible, Non-Native Models in ESL/EFL Pronunciation Teaching. Elsevier.

https://www.sciencedirect.com/science/article/pii/S0346251X13001838.\%0A

Olaf, H. (1963). Systematic Use of Experts in Operations Research. Atherton Press.

Pourhosein, G. (2012). Teaching Pronunciation of English with Computer Technology: A Qualitative Study. Internation Journal of Research in English Education.

Shannon, M. (2014). Prononciation in Second Language Teaching (5th ed.). Annual Proceedings of University Iowa.

Vina, F., \& Utami., S. (2019). Implementing an Android-Based Learning Media Application to Improve Learners' Ability in Pronouncing. J-SHMIC: Journal of English for Academic, 6(2), 14-26.

Yolanda, B. (2017). Contributions of New Technologies to The Teaching of English Pronunciation. Language Value, 9, 1-35. 